Bull. Chem. Soc. Ethiop. 2003, 17(1), 95-106.

ISSN 1011-3924

Printed in Ethiopia

(c) 2003 Chemical Society of Ethiopia

\title{
ELECTROCHEMICAL OXIDATION OF NICLOSAMIDE AT A GLASSY CARBON ELECTRODE AND ITS DETERMINATION BY VOLTAMMETRY
}

\author{
Hailemichael Alemu*, Ntai M. Khoabane and Potlaki F. Tseki \\ Department of Chemistry, National University of Lesotho, P.O. Roma 180, Roma, Lesotho, \\ Southern Africa
}

(Received August 8, 2002; revised February 22, 2003)

\begin{abstract}
Cyclic voltammetry, square-wave voltammetry and controlled potential electrolysis have been used to study the electrochemical oxidation behaviour of niclosamide at a glassy carbon electrode. The number of electrons transferred, the wave characteristics, the diffusion coefficient and reversibility of the reactions have been investigated. Following optimisation of voltammetric parameters, $\mathrm{pH}$, and reproducibility, a linear calibration curve over the range $1 \times 10^{-6}-1 \times 10^{-4}$ mol dm ${ }^{-3}$ niclosamide was achieved. The detection limit was found to be $8 \times 10^{-7} \mathrm{~mol} \mathrm{dm}^{-3}$. For eight successive determinations of $1 \times 10^{-5} \mathrm{~mol} \mathrm{dm}^{-3}$ niclosamide, a relative standard deviation of $3.6 \%$ was obtained. This voltammetric method was applied for the determination of niclosamide in tablets.
\end{abstract}

KEY WORDS: Niclosamide, Electrochemical oxidation, Cyclic voltammetry, Square wave voltammetry, Glassy carbon electrode, Determination of niclosamide

\section{INTRODUCTION}

Niclosamide (2',5-dichloro-4'-nitrosalicylanilide, NA, Figure 1) is a relatively selective, noncumulative chlorinated aromatic amide pesticide. It is principally used against aquatic snails but also as an anti-parasitic drug that is effective against all the species of tapeworm infections [13]. Its mode of action against tapeworm species is to uncouple oxidative phosphorylation and blocking the glucose uptake and inhibits respiration in cestodes $[4,5]$. NA is toxic to aquatic vertebrates (e.g. fish and amphibians) and crustaceans, but has very low toxicity to mammals. It is non-persistent in the aquatic environment, has a slight effect on aquatic plants and zooplankton, but is not generally phytotoxic at field concentration. Formulated as the ethanolamine salt, or piperazine salt, or niclosamide monohydrate, it is one of the most effective and widely used molluscicides for the control of snail vectors of schistosomiasis, a parasitic disease affecting over 200 million people in more than seventy countries [6].

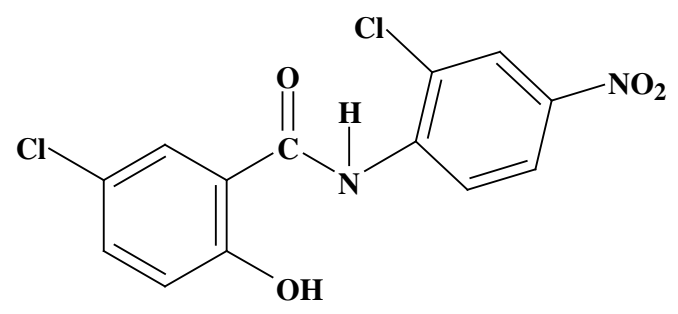

Figure 1. Structure of niclosamide (2',5-dichloro-4'-nitrosalicylanilide).

*Corresponding author. E-mail: hm.alemu@nul.ls 
Several methods have been reported for the determination of NA. These include spectrophotomteric techniques on derivatives or complexes of niclosamide [7-14], high performance liquid chromatography (HPLC) [15-17], gas-liquid chromatography [18], and polarography [19]. Most of these techniques involve complex formation or derivatization of NA that affects the sensitivity and selectivity of NA determination. The polarographic method is based on the reduction of NA and has very narrow linear range. HPLC or GC methods have been officially recognised $[20,21]$.

Very recently, we reported the electrochemical reduction of NA at a glassy carbon electrode using cyclic voltammetry and its direct determination by square-wave voltammetry [22]. Very sensitive and selective procedure was developed and it was demonstrated that using the developed method NA can be determined over the range $5 \times 10^{-8}-1 \times 10^{-6} \mathrm{~mol} \mathrm{dm}^{-3}$.

The aim of the present study was to examine the electro-oxidation behaviour of this substance at solid electrodes that has not been reported elsewhere and to develop analytical procedure for its determination.

Hence, in the present study the electrochemical oxidation behaviour of NA at a glassy carbon electrode is described for the first time and based on the oxidation wave a voltammetric procedure has been developed. This method has a wider linear dynamic range $\left(1 \times 10^{-6}-1 \times 10^{-4}\right.$ mol $\mathrm{dm}^{-3}$ ). The method was applied successfully to the determination of NA in pharmaceutical tablets.

\section{EXPERIMENTAL}

\section{Apparatus}

A BAS 100B electrochemical analyser (Bioanalytical Systems) was used for cyclic and squarewave voltammetry, with a three-electrode system consisting of a glassy carbon disk working electrode (BAS MF-2012), an $\mathrm{Ag} / \mathrm{AgCl}(3 \mathrm{M} \mathrm{NaCl}$ ) reference electrode (BAS MF-2052), and a platinum wire auxiliary electrode (BAS MW-1032). Before each experiment the glassy carbon electrode was polished manually with alumina $(\phi: 0.01 \mu \mathrm{m})$ on a micro-cloth pad and rinsed with distilled and de-ionized water.

The active surface area of the working electrode was determined experimentally using 0.05 mol dm${ }^{-3} \mathrm{~K}_{3}\left[\mathrm{Fe}(\mathrm{CN})_{6}\right]$ in $0.1 \mathrm{~mol} \mathrm{dm}^{-3} \mathrm{KCl}$ and cyclic voltammetry at different scan rates and by the Randels-Sevcik equation. Using the diffusion coefficient of hexacyanoferrat, $8.96 \times 10^{-6} \mathrm{~cm}^{2}$ $\mathrm{s}^{-1}$ [23], the active surface area was determined $0.06 \mathrm{~cm}^{2}$. This electrode was used for all voltammetric measurements except for controlled potential electrolysis.

The $\mathrm{pH}$ of the buffer solution was measured with Hanna instruments digital $\mathrm{pH}$ meter with a glass combination electrode and with accuracy of $\pm 0.05 \mathrm{pH}$. All potentials are reported with respect to $\mathrm{Ag} / \mathrm{AgCl}\left(3 \mathrm{~mol} \mathrm{dm}^{-3} \mathrm{NaCl}\right)$ reference electrode.

\section{Reagents}

Niclosamide was obtained from Sigma (USA), 2-chloro-4-nitroaniline from Aldrich (USA), 5chloro-2-hydroxybenzoic acid from Merck-Schuchardt (Germany), methanol from Merck (South Africa), ethanol and ammonium chloride from Saarchem (South Africa), ammonia solution and sodium perchlorate from Riedel-de Haen (Germany), and sodium hydroxide from ACE (South Africa) and were used as received. Distilled, de-ionised water was used throughout.

Ammonia-ammonium chloride buffers in the $\mathrm{pH}$ range 8-11 were prepared from $0.1 \mathrm{~mol}$ $\mathrm{dm}^{-3}$ ammonia solution and $0.1 \mathrm{~mol} \mathrm{dm}^{-3}$ ammonium chloride in water. The $\mathrm{pH}$ of the solutions was adjusted by adding acetic acid or $1 \mathrm{~mol} \mathrm{dm}^{-3}$ sodium hydroxide. Stock solutions of niclosamide, $2 \times 10^{-3} \mathrm{~mol} \mathrm{dm}^{-3}$ were prepared daily in pure methanol and kept in the dark. The 
working solutions for the voltammetric investigations were prepared by dilution of the stock methanolic solution with aqueous buffer solutions. All stock solutions were protected from light and were used within several hours to avoid decomposition.

\section{Procedure}

Cyclic voltammetric measurements were run from an initial potential of -0.2 to a switching potential of $1.2 \mathrm{~V}$ at a glassy carbon electrode with a scan rate of $100 \mathrm{mV} \mathrm{s}^{-1}$. The scan rate was varied from 0.005 to $0.2 \mathrm{~V} \mathrm{~s}^{-1}$ to study the dependence of the peak current and the peak potential on the scan rate. Square wave voltammetric measurements were run from 0.15 to $1.2 \mathrm{~V}$ using the Osteryoung square wave voltammetric mode and the net current responses were recorded. The step was $10 \mathrm{mV}$, the square wave amplitude was $35 \mathrm{mV}$, and the square wave frequency was $45 \mathrm{~Hz}$. All measurements were carried out at ambient laboratory temperature $\left(22 \pm 2{ }^{\circ} \mathrm{C}\right)$ and without purging the solution with inert gas.

Controlled potential electrolysis of NA was performed at another glassy carbon electrode of large surface area $\left(0.79 \mathrm{~cm}^{2}\right)$ in $0.1 \mathrm{~mol} \mathrm{dm}{ }^{-3} \mathrm{NH}_{3}-\mathrm{NH}_{4} \mathrm{Cl}$ aqueous solution for three NA concentrations $\left(\mathrm{c}=1 \times 10^{-4}, 2 \times 10^{-4}, 8 \times 10^{-4} \mathrm{~mol} \mathrm{dm}^{-3}\right)$. Solutions were stirred during electrolysis using a magnetic stirring bar. The electrolysis was terminated when the electrolytic current decreased to the residual current value measured in the supporting electrolyte prior to addition of the analyte.

\section{Analysis of tablets}

Five tablets of niclosamide (EPHARM), each weighing $650 \mathrm{mg}$ and containing $500 \mathrm{mg}$ niclosamide were ground to a powder and thoroughly mixed. From the ground tablets $42.52 \mathrm{mg}$ were taken and dissolved in $100 \mathrm{~cm}^{3}$ methanol in order to obtain $1 \times 10^{-3} \mathrm{~mol} \mathrm{dm} \mathrm{dA}^{-3} \mathrm{NA}$. This was diluted to $1 \times 10^{-4} \mathrm{~mol} \mathrm{dm}^{-3}$ with the supporting electrolyte solution. An aliquot of this solution $\left(0.025 \mathrm{~cm}^{3}\right)$ was spiked into the electrochemical cell that contained $20 \mathrm{~cm}^{3}$ of $0.1 \mathrm{M} \mathrm{NH}_{3}-\mathrm{NH}_{4} \mathrm{Cl}$ buffer ( $\mathrm{pH} \mathrm{8.5)}$ and the voltammogram was recorded following the above outlined voltammetric procedure and optimised parameters for square wave voltammetry. The standard addition method was applied, adding successive aliquots of $0.025 \mathrm{~cm}^{3}$ of $1 \times 10^{-4} \mathrm{~mol} \mathrm{dm} \mathrm{d}^{-3} \mathrm{NA}$ standard solution to the electrochemical cell. Square wave voltammograms were recorded by scanning anodically from 0.15 to $1.2 \mathrm{~V}$. The net peak current of the oxidation wave at $0.67 \mathrm{~V}$ was measured. The calibration graph was then constructed by plotting the net peak current against NA concentration.

\section{RESULTS AND DISCUSION}

\section{Cyclic voltammetry oxidation behaviour of NA}

Electrochemical oxidation of NA can take place via the phenol group at the side chain of the molecule. In the present study carbon paste, glassy carbon, gold and platinum electrodes were tested in the oxidation of NA. No response was obtained with carbon paste, gold and platinum electrodes in the potential range investigated.

The cyclic voltammogram for the oxidation of $4 \times 10^{-4} \mathrm{~mol} \mathrm{dm}{ }^{-3} \mathrm{NA}$ at a glassy carbon electrode in $\mathrm{NH}_{3}-\mathrm{NH}_{4} \mathrm{Cl}(\mathrm{pH}$ 8.5) is shown in Figure 2. During the first cycle an irreversible oxidation peak appeared at $0.724 \mathrm{~V}$ on the anodic scan. On the reverse scan no corresponding reduction peak was observed. The oxidation of NA was investigated at different $\mathrm{pH}$ buffer solutions. In the $\mathrm{pH}$ range $8-11$ only a single irreversible oxidation peak was exhibited. In this $\mathrm{pH}$ range the peak potential showed a shift of about $30 \mathrm{mV}$ per $\mathrm{pH}$ that decreased with increase 
in $\mathrm{pH}$ indicating the involvement of $\mathrm{H}^{+}$ion in the electron transfer process. When the $\mathrm{pH}$ was decreased below 7 the oxidation peak disappeared completely.

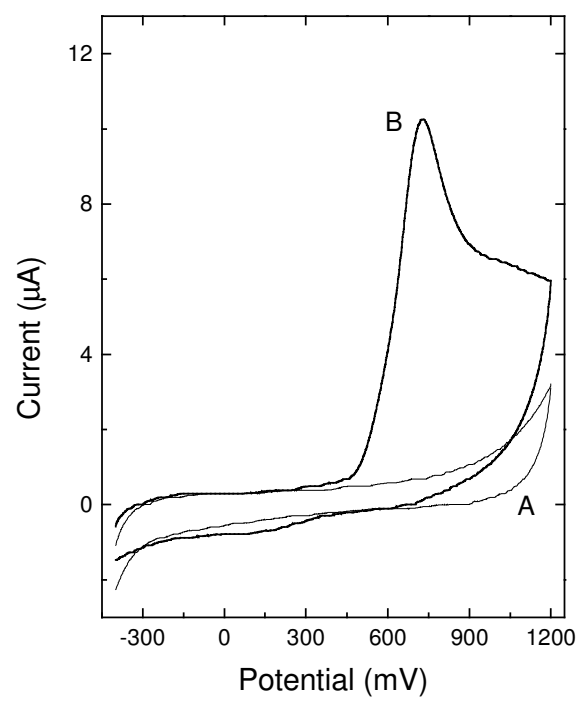

Figure 2. Cyclic voltammograms of aqueous $0.1 \mathrm{~mol} \mathrm{dm}^{-3} \mathrm{NH}_{3}-\mathrm{NH}_{4} \mathrm{OH}, \mathrm{pH} 8.5$ (A) and 4 x $10^{-4}$ mol dm ${ }^{-3} \mathrm{NA}(\mathrm{B})$.

Organic compounds whose oxidation potentials are $\mathrm{pH}$ dependent undergo deprotonation reaction during oxidation. Below $\mathrm{pH} 7$ it is apparent that the $\mathrm{NH}$ group of NA molecule is protonated to a great extent and hence presumably the oxidation of NA is precluded. The absence of the oxidation peak at low $\mathrm{pH}$ further suggests the involvement of the $\mathrm{NH}$ group in the charge transfer as well as deprotonation steps of the process.

The oxidation of NA at glassy carbon electrode gave rise to chemically irreversible process over the scan rate range of $5 \mathrm{mV} \mathrm{s}^{-1}$ to $5 \mathrm{~V} \mathrm{~s}^{-1}$. Figure 3 shows the cyclic voltammograms of $8 \mathrm{x}$ $10^{-4} \mathrm{~mol} \mathrm{dm} \mathrm{dm}^{-3} \mathrm{NA}$ solution at different scan rates. The peak potential for the process becomes more positive as the scan rate increases while the peak currents are proportional to the square root of the scan rate, for the scan rate up to $200 \mathrm{mV} \mathrm{s}^{-1}$, as expected when the mass transport process is diffusion controlled [24, 25]. At scan rates greater than $200 \mathrm{mV} \mathrm{s}^{-1}$, the NA oxidation process loses the characteristic diffusion controlled peak shape and becomes broad and sigmoidal shaped implying that surface based process becomes dominant at high scan rates [26]. The effect of the potential scan rate $v$ on the peak current for different concentrations of NA was studied. The peak current is proportional to the square root of scan rate $v^{1 / 2}$ for all concentrations of NA studied as predicted for a diffusion controlled regime. The linearity of the plots is described by the following equations:

$$
\begin{aligned}
& \mathrm{i}_{\mathrm{p}} / \mu \mathrm{A}=-0.052 / \mu \mathrm{A}+6.304 \mathrm{v}^{1 / 2} ; \mathrm{r}^{2}=0.998 ; \text { for } \mathrm{c}=1 \times 10^{-4} \mathrm{~mol} \mathrm{dm}^{-3} \\
& \mathrm{i}_{\mathrm{p}} / \mu \mathrm{A}=0.044 / \mu \mathrm{A}+10.542 \mathrm{v}^{1 / 2} ; \mathrm{r}^{2}=0.997 ; \text { for } \mathrm{c}=2 \times 10^{-4} \mathrm{~mol} \mathrm{dm}^{-3} \\
& \mathrm{i}_{\mathrm{p}} / \mu \mathrm{A}=-0.294 / \mu \mathrm{A}+44.170 \mathrm{v}^{1 / 2} ; \mathrm{r}^{2}=0.999 ; \text { for } \mathrm{c}=8 \times 10^{-4} \mathrm{~mol} \mathrm{dm}^{-3}
\end{aligned}
$$




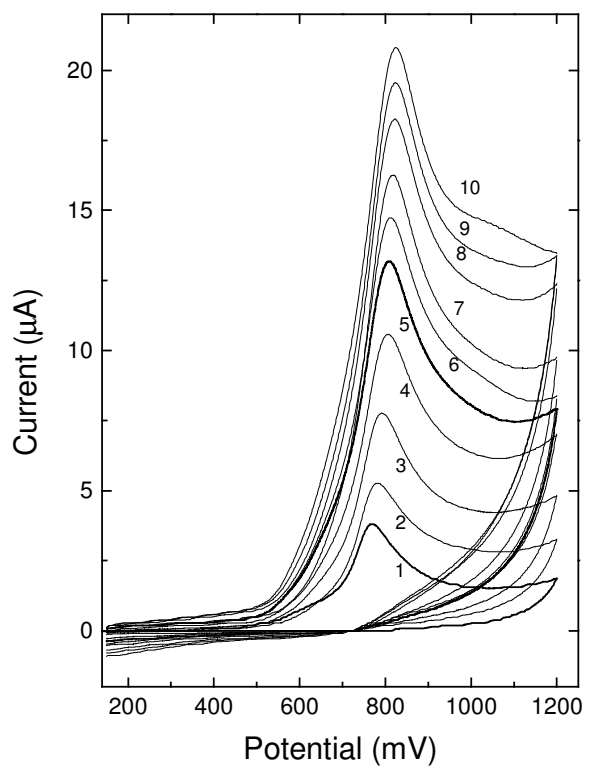

Figure 3. Cyclic voltammograms of $8 \times 10^{-4} \mathrm{~mol} \mathrm{dm}{ }^{-3} \mathrm{NA}$ at different scan rates; (1) 5 ; (2) 10 ; (3) 20 ; (4) 40; (5) 60; (6) 80; (7) 100; (8) 120; (9) 140; (10) $160 \mathrm{mV} \mathrm{s}^{-1}$.

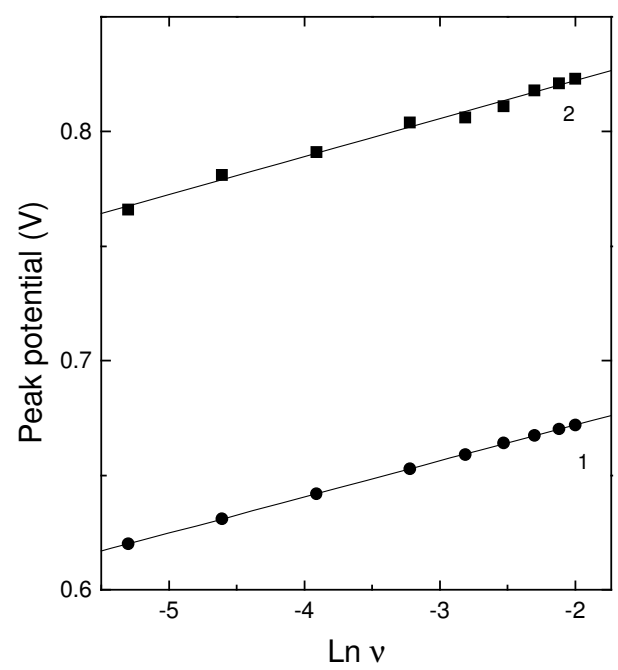

Figure 4. Dependence of the peak potential on the logarithm of the scan rate, (1) $2 \times 10^{-4}$; (2) $8 \mathrm{x}$ $10^{-4} \mathrm{~mol} \mathrm{dm}^{-3} \mathrm{NA}$.

Bull. Chem. Soc. Ethiop. 2003, 17(1) 
Figure 4 shows the dependence of the peak potential of NA on the logarithm of the potential scan rate for two different concentrations of NA. The peak potential is directly proportional to the logarithm of the scan rate and the linear plots are expressed as follows:

$$
\begin{aligned}
& E_{p} / V=0.704+0.0158 \ln v ; r^{2}=0.999 ; \text { for } c=1 \times 10^{-4} \mathrm{~mol} \mathrm{dm}^{-3} \\
& E_{p} / V=0.855+0.0165 \ln v ; r^{2}=0.996 ; \text { for } c=1 \times 10^{-8} \mathrm{~mol} \mathrm{dm}^{-3}
\end{aligned}
$$

Constant potential electrolysis of NA was carried out at $0.800 \mathrm{~V}$ for three concentrations of $\mathrm{NA},\left(\mathrm{c}=1 \times 10^{-4}, 2 \times 10^{-4}, 8 \times 10^{-4} \mathrm{~mol} \mathrm{dm}^{-3}\right)$ to determine the number of electrons transferred in the process. From the electrolysis results, the average number of electrons $n$ transferred per molecule was found to be $1.9 \pm 0.2$.

For a totally irreversible oxidation reaction the peak current at $25{ }^{\circ} \mathrm{C}$ is given by:

$$
\mathrm{i}=\left(2.99 \times 10^{5}\right) \mathrm{n}\left[(1-\alpha) \mathrm{n}_{\alpha}\right]^{1 / 2} \mathrm{Ac}_{\mathrm{b}} \mathrm{D}^{1 / 2} \mathrm{v}^{1 / 2}
$$

where $\mathrm{A}$ in $\mathrm{cm}^{2}, \mathrm{D}$ in $\mathrm{cm}^{2} \mathrm{~s}^{-1}, \mathrm{c}_{\mathrm{b}}$ in $\mathrm{mol} \mathrm{cm} \mathrm{cm}^{-3}, v$ in $\mathrm{V} \mathrm{s}^{-1}$ and $\mathrm{n}_{\alpha}$ is the number of electrons transferred up to, and including the rate determining step [24-27]. The peak potential is related to the scan rate $v$ with the following relation:

$$
\mathrm{E}_{\mathrm{p}}=\mathrm{K}+\left[\mathrm{RT} / 2(1-\alpha) \mathrm{n}_{\alpha} \mathrm{F}\right] \ln v
$$

where $K=E^{o}+\left[R T /(1-\alpha) n_{\alpha} F\right]\left[0.78+(1 / 2) \ln \left[(1-\alpha) n_{\alpha} F\right.\right.$ D/k $\left.k^{02} R T\right]$

Using equation (7) and $\mathrm{t}=25^{\circ} \mathrm{C}$, the value of $(1-\alpha) \mathrm{n}_{\alpha}$ was determined from the slope of $\mathrm{E}_{\mathrm{p}}$ vs $\ln v$ (equations (4) and (5)) as 0.78 and 0.82 , respectively. The electron transfer coefficient $\alpha$ for the oxidation of NA was determined $(\alpha=0.67)$ from the Tafel slope of a linear scan voltammogram at low scan rate $\left(5 \mathrm{mV} \mathrm{s}^{-1}\right)$ [28]. Thus the $\mathrm{n}_{\alpha}$ value was estimated to be 2 . The $(1-\alpha) n_{\alpha}$ values were then inserted into equation (6) and the diffusion coefficient was determined for $1 \times 10^{-4}$ and $8 \times 10^{-4} \mathrm{~mol} \mathrm{dm} \mathrm{dm}^{-3} \mathrm{NA}$ to be $3.04 \times 10^{-6}$ and $3.76 \times 10^{-6} \mathrm{~cm}^{2} \mathrm{~s}^{-1}$, respectively, giving an average diffusion coefficient of $3.40 \times 10^{-6} \mathrm{~cm}^{2} \mathrm{~s}^{-1}$. This value is reasonably in good agreement when compared to the diffusion coefficient of salicylate $\left(D=9.6 \times 10^{-6} \mathrm{~cm}^{2} \mathrm{~s}^{-1}\right)$ that has similar structure but much lesser molecular weight [23].<smiles>CC(C)[C@H](C)C(=O)c1cc(Cl)ccc1[N+](=O)[O-]</smiles><smiles>O=C(N[C+]([I-])c1ccc([N+](=O)[O-])cc1Cl)c1cc(Cl)ccc1[N+](=O)[O-]</smiles>

Scheme 1 
The electrochemical oxidation of a series of Schiff bases that have similar structures like NA was studied $[29,30]$. The mechanism was investigated and found to proceed by oxidation of the protonated substrate to give a radical cation. The radical cation is deprotonated and further oxidised to form a di-radical cation which after losing another proton cyclizes to give product. On the basis of these literature findings and taking into account the results of $\mathrm{pH}$ effect, logarithmic analysis, cyclic voltammetry and controlled potential electrolysis, an oxidation pathway for NA at glassy carbon electrode is hereby proposed (Scheme 1).

Square wave voltammetry

For the determination of NA both Osteryoung square wave and differential pulse techniques were tested. It was found out that square wave voltammetry (SWV) was superior in terms of peak intensity and resolution than the differential pulse voltammetry. Hence, SWV was utilised throughout this study. In order to establish the optimum conditions for the determination of NA by means of SWV, the effects of various instrumental variables were studied. The SWV parameters are interrelated and have a combined influence on the peak current [31].

For the optimisation of instrumental conditions, the square wave frequency (f), the potential step $\left(\Delta \mathrm{E}_{\mathrm{s}}\right)$ and the pulse amplitude $(\Delta \mathrm{E})$ were examined, varying one of them and maintaining constant the others. The variable ranges were: $2-10 \mathrm{mV}$ for the potential step; $5-70 \mathrm{~Hz}$ for the frequency and $12-40 \mathrm{mV}$ for the pulse amplitude. The net peak current increased by increasing all of these instrumental parameters. At higher potential step values the peak width increased and at higher frequency values the background current and the peak potential increased. Finally the conditions selected were: $\Delta \mathrm{E}_{\mathrm{s}}=10 \mathrm{mV}, \mathrm{f}=45 \mathrm{~Hz}$ and $\Delta \mathrm{E}=35 \mathrm{mV}$.

The influence of the initial sweep potential on $\Delta \mathrm{I}_{\mathrm{p}}$ was examined in the potential range -200 to $250 \mathrm{mV}$. The analytical signal size is influenced by the initial sweep potential and the net peak current was found to increase rapidly with increasing the potential up to $100 \mathrm{mV}$ and then remained constant (Figure 5). Therefore, initial sweep potential of $150 \mathrm{mV}$ was chosen for all subsequent measurements.

\section{Effect of buffer solutions}

Different types of buffer solutions were tested for their suitability in the determination of NA: phosphate buffer, $\mathrm{KH}_{2} \mathrm{PO}_{4}-\mathrm{Na}_{2} \mathrm{HPO}_{4}$; acetate buffer, $\mathrm{CH}_{3} \mathrm{COOH}-\mathrm{CH}_{3} \mathrm{COONa}$; borate buffer, $\mathrm{H}_{3} \mathrm{BO}_{3}-\mathrm{NaBO}_{2}$; and ammonia buffer, $\mathrm{NH}_{3}-\mathrm{NH}_{4} \mathrm{Cl}$. There was no voltammetric signal detected in acidic buffer system. The most suitable buffer system was found to be $0.1 \mathrm{~mol} \mathrm{dm}^{-3}$ aqueous $\mathrm{NH}_{3}-\mathrm{NH}_{4} \mathrm{Cl}$, since the voltammogram of niclosamide was well defined with higher sensitivity.

\section{Effect of $p H$}

The influence of $\mathrm{pH}$ on the net peak current of niclosamide was investigated over the range of $\mathrm{pH} \mathrm{8-11} \mathrm{(Figure} \mathrm{6).} \mathrm{Low} \mathrm{and} \mathrm{constant} \mathrm{current} \mathrm{signals} \mathrm{are} \mathrm{obtained} \mathrm{between} \mathrm{pH} 10$ and 11. Between $\mathrm{pH} 8$ and 9.5 the response increased with decreasing $\mathrm{pH}$. The largest peak signal was obtained at $\mathrm{pH} 8.5$. Thus $\mathrm{pH} 8.5$ was selected for the analysis. 


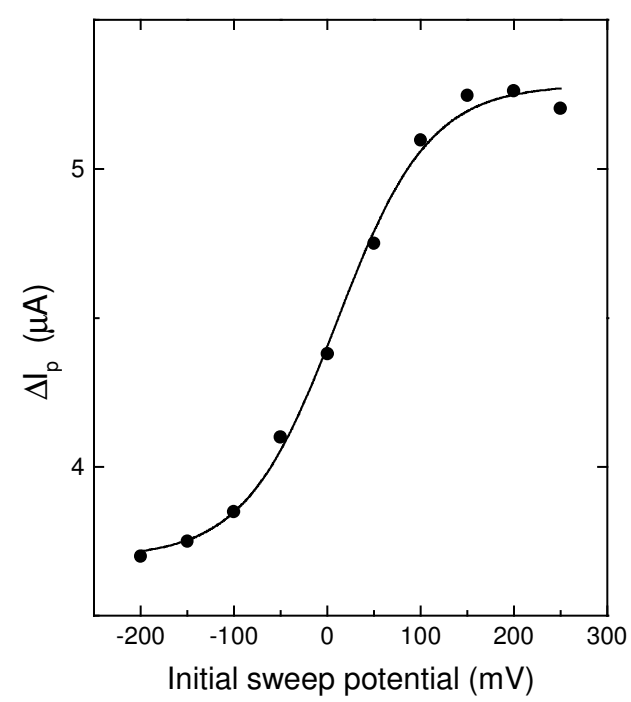

Figure 5. The effect of the initial sweep potential on the net peak current for $1 \times 10^{-4} \mathrm{~mol} \mathrm{dm}^{-3}$ NA.

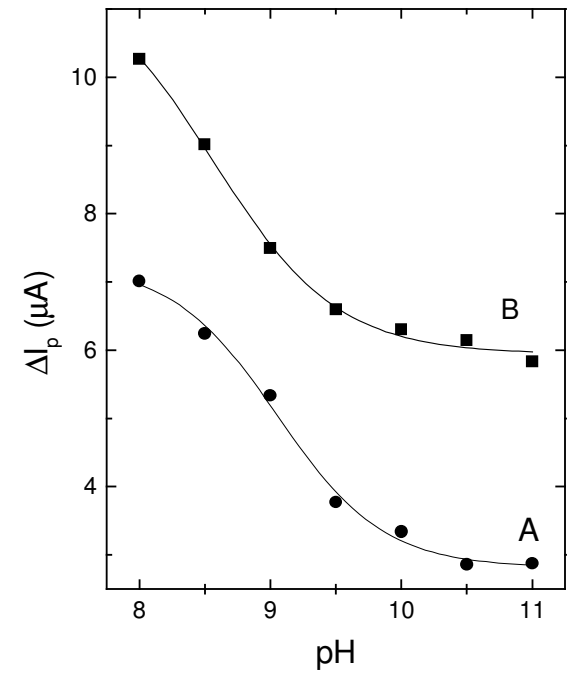

Figure 6. The influence of $\mathrm{pH}$ on the net peak current for $1 \times 10^{-4} \mathrm{~mol} \mathrm{dm}^{-3}$ (A) and $2 \times 10^{-4} \mathrm{~mol}$ $\mathrm{dm}^{-3} \mathrm{NA}(\mathrm{B})$.

Bull. Chem. Soc. Ethiop. 2003, 17(1) 
Linear range and detection limit

Under the optimum conditions, using the square-wave mode the peak current was linearly dependent on NA concentration. Selected square wave voltammograms at different concentrations of NA are shown in Figure 7A. The dependence of the net peak current as a function of the concentration of NA is also shown in Figure 7B. Each data point in Figure 7B is the mean value of the net peak currents for three SWV runs. The net peak current increased with increasing concentration of NA. The response was found to be linear in the concentration range $1.00 \times 10^{-6}-1.00 \times 10^{-4} \mathrm{~mol} \mathrm{dm}{ }^{-3} \mathrm{NA}$ and the correlation coefficient was $\mathrm{r}^{2}=0.999$. At higher concentrations $\left(\geq 2 \times 10^{-4} \mathrm{M}\right)$ deviation from linearity occurred due to saturation of the electrode surface. The detection limit (three times signal-to-noise ratio) was found to be $8 \times 10^{-7} \mathrm{~mol} \mathrm{dm}^{-3}$ NA. For eight successive determinations of $1 \times 10^{-5} \mathrm{~mol} \mathrm{dm}^{-3} \mathrm{NA}$, a relative standard deviation (RSD) of 3.6\% was obtained. Consistent electrode surface cleaning after each experimental run enhanced the reproducibility of the results. Thus, uniform electrode surface cleaning is recommended after each measurement.

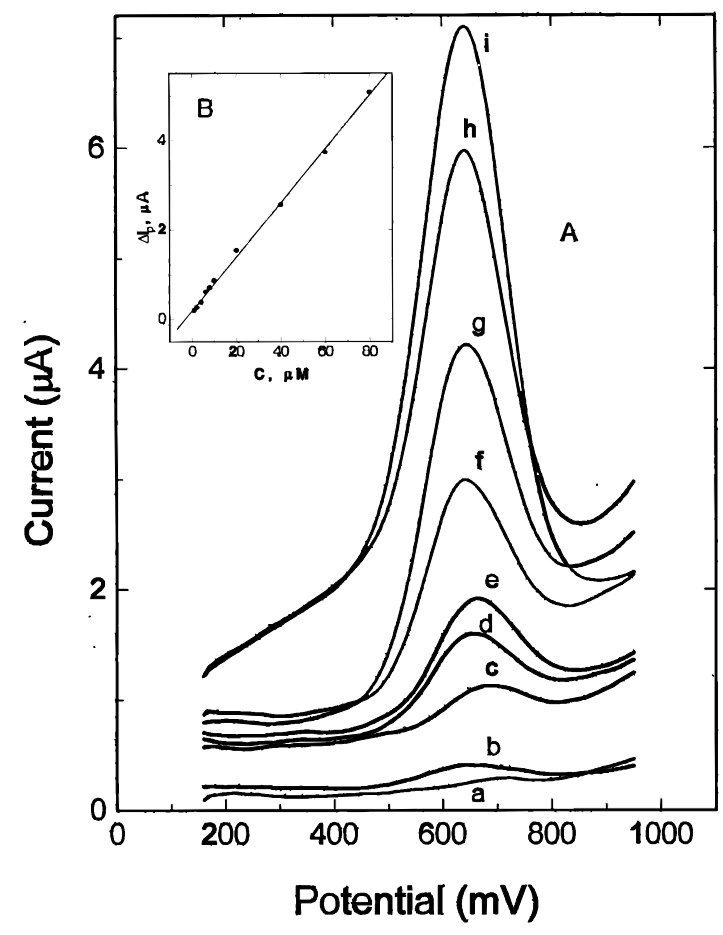

Figure 7. Osteryoung square wave voltammograms of NA (A). (a) 0 ; (b) $1 \times 10^{-6}$; (c) $2 \times 10^{-6}$; (d) $4 \times 10^{-6}$; (e) $6 \times 10^{-6}$; (f) $8 \times 10^{-6}$; (g) $1 \times 10^{-5}$; (h) $2 \times 10^{-5}$; (i) $4 \times 10^{-5}$. The net peak currents of niclosamide as a function of concentration of NA in the range $1 \times 10^{-6}-1 \mathrm{x}$ $10^{-4} \mathrm{~mol} \mathrm{dm}^{-3}(\mathrm{~B})$. 
Interferences and selectivity

The effect of the concomitants associated with NA in its pure form and its formulations were tested using the developed method. This method does not suffer any interference from commonly associated sweetening and flavouring agents used in the preparation of tablets, such as sucrose, lactose, dextrose, starch, talc, stearic acid and sodium alginate with respect to known amount of NA. The mean recovery was $98.83 \%$.

The selectivity of the method was tested by examining 2-chloro-4-nitroaniline and 5chlorosalicylic acid. These compounds are disintegration products of NA that are routinely tested in the drug manufacturing of NA [2, 4]. 5-Chlorosalicylic acid and 2-chloro-4-nitroaniline gave irreversible oxidation peaks at more positive potentials than NA. The presence of five fold molar excess of 5-chlorosalicylic acid and 2-chloro-4-nitroaniline in NA, respectively, did not affect the peak current of NA. These observations indicate that the method is very selective for NA.

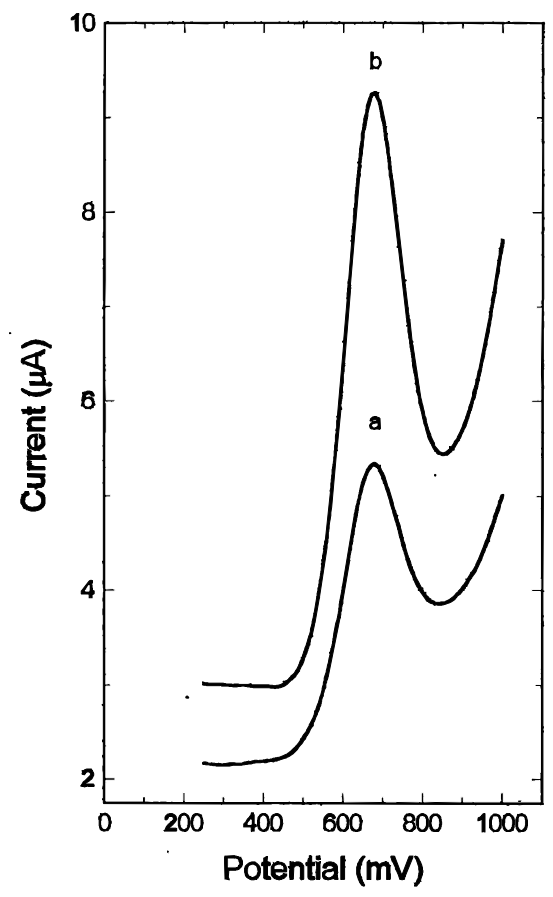

Figure 8. Osteryoung square wave voltammograms of NA tablets at a glassy carbon electrode in $0.1 \mathrm{~mol} \mathrm{dm}^{-3} \mathrm{NH}_{3}-\mathrm{NH}_{4} \mathrm{OH}$ buffer (pH 8.5); (a) $1 \times 10^{-5}$ and (b) $4 \times 10^{-5} \mathrm{~mol} \mathrm{dm}^{-3} \mathrm{NA}$. Other experimental conditions as in Figure 7.

\section{Analytical application}

Figure 8 shows the square wave voltammograms of NA tablet for two concentrations $(\mathrm{c}=1 \mathrm{x}$ $10^{-5}$ and $4 \times 10^{-5} \mathrm{~mol} \mathrm{dm}^{-3}$ ) prepared without any purification. The proposed method was applied

Bull. Chem. Soc. Ethiop. 2003, 17(1) 
to the determination of niclosamide in tablets by using the standard additions method. The procedure used for the determination of NA as described earlier gave a mean value of $495.2 \mathrm{mg}$ of NA per tablet. This is in very good agreement with the declared value of $500 \mathrm{mg}$.

\section{CONCLUSION}

This study presents the electrochemical oxidation behaviour and analytical determination of NA. The cyclic voltammetric response obtained is chemically irreversible over the range of scan rates employed, and is consistent with electron transfer being followed by fast chemical process. Successful application of SWV for the determination of NA in pharmaceutical formulation is demonstrated. The method is relatively cheap and rapid in comparison with other methods and avoids time-consuming extraction steps to remove the excipients from tablets. Combining the present method with the recently reported voltammetric method [22] gives a very wide linear range for the determination of NA.

\section{ACKNOWLEDGEMENTS}

The authors are grateful for the procurement of instruments by the Ministry of Education for the National University of Lesotho, Chemistry Department. The Department of Chemistry is acknowledged for both the material and financial support.

\section{REFERENCES}

1. Jones, W.E. Am. J. Trop. Med. Hyg. 1979, 28, 300.

2. Remington's Pharmaceutical Sciences, Mack Publishing Co.: Easton, Pennsylvania; 1980, $\mathrm{p}$ 1182.

3. Data Sheet on Pesticides No 63, World Health Organization, Food and Agriculture Organization; WHO/VBC/DS/88.63, 1988.

4. Korlkovas, A. Essentials of Medicinal Chemistry, John Wiley: New York; 1988; p 617.

5. Reynolds, E.F. Martindale The Extra Pharmacopoei, The Pharmaceutical Press: London; 1982; p 100.

6. Churchill, F.C.; Ku, D.N. J. Chromatogr. 1980, 189, 375.

7. Bergisadi, N.; Sarigul, D. Acta Pharm. Turc. 1986, 28, 51.

8. Zarapkar, S.S.; Mehron, S.S; Rele, S.R. Indian Drugs 1989, 26, 360.

9. Onur, F.; Tekin, N. Anal. Lett. 1994, 27, 229.

10. Zarapkar, S.S.; Deshpande, P.M. Indian J. Pharm. Sci.1989, 51, 136.

11. Sastry, C.P.; Amna, M.; Rao, A.R. Talanta 1988, 35, 23.

12. Sastry, C.P.; Amna, M; Rao, A.R. Indian Drugs 1988, 25, 348.

13. Fattah, S.A. Spectrosc. Lett. 1997, 30, 795.

14. Daabees, H.G. Anal. Lett. 2000, 33, 639.

15. Derek, C.G.; Norbert, P. Int. J. Environ. Anal. Chem. 1980, 8, 1.

16. Dawson, V.K. Can. J. Fish. Aquat. Sci. 1982, 39, 778.

17. Schreier, M.T.; Dawson, K.V.; Boogaard, A.M. J. Agric. Food Chem. 2000, 48, 2212.

18. Johnson, S.J.; Geoffrey, B.P. Pestic. Sci. 1979, 10, 531.

19. Mishra, A.K.; Gode, K.D. Indian Drugs 1985, 22, 317.

20. Muir, D.C.G.; Grift, N.P. Int. J. Environ. Anal. Chem. 1980, 8, 1. 
21. Luhning, C.W.; Harmann, P.D.; Sills, J.B.; Dawson, V.K.; Allen, J. J. Ass. Off. Analyt. Chem. 1979, 62, 1141.

22. Alemu, H.; Wagana, P.; Tseki, P. Analyst, 2002, 127, 129.

23. Lide, D.R. CRC Handbook of Chemistry and Physics, CRC Press: Boca Raton; 1997.

24. Southampton Electrochemistry Group Instrumental Methods in Electrochemistry, Ellis Horwood; Chichester; 1985.

25. Brown, E.R.; Sandifer, J.R. Physical Methods of Chemistry, Volume II, Electrochemical Methods, Rossiter, W.; Hamilton, J.F. (Eds.); Wiley-Interscience: New York; 1986.

26. Coomber, D.C.; Tucker, D.J.; Bond, A.M. Electroanalysis, 1998, 10, 163.

27. Golabi, S.M.; Zare, H.R.; Hamzehloo, M. Microchem. J. 2001, 69, 111.

28. Bard, A.J.; Faulkner, L.R. Electrochemical Methods Fundamentals and Applications, John Wiley: New York; 1980.

29. Lacan, M.; Rogic, V.; Tabakovic, I.; Galijas, D.; Solomun, T. Electrochim. Acta 1983, 28, 199.

30. Pletcher, D. Specialist Periodical Reports, Electrochemistry, 1985, Royal Society of Chemistry, Burlington House: London; pp 208-209.

31. Christie, J.H.; Turner, J.A.; Osteryoung, R.A. Anal. Chem. 1977, 49,1899. 